\author{
Anita Gulczyńska \\ Uniwersytet Łódzki \\ anigul@wp.pl
}

\author{
Monika Wiśniewska-Kin \\ Uniwersytet Łódzki \\ monikawk@uni.lodz.pl
}

\title{
Dyskurs edukacyjny w badaniach. Próba systematyzacji perspektyw badawczych
}

\section{Summary \\ Educational discourse in the research. Draft framework of research perspectives}

Our aim throughout the contribution was to systemize perspectives employed by the researchers in the studies of educational discourse. Three perspectives of empirical insight into educational discourses were reconstructed in the course of our analysis of selected research examples: optimizing, analytic and critical. The criterion underpinning the analysis was a pragmatic function of the studies. Hence, the links between the choice of research perspective, results of research and practical implications for school improvement were discussed.

Slowa kluczowe: wczesna edukacja, dyskurs edukacyjny, perspektywa optymalizująca, perspektywa analityczna, perspektywa krytyczna.

Keywords: early school education, educational discourse, optimizing perspective, analytic perspective, critical perspective

Mimo skategoryzowania dyskursu jako zasadniczego pojęcia umożliwiającego odnajdywanie i formułowanie nowych problemów i zagadnień w naukach społecznych, lektura dotychczasowych diagnoz w obszarze badań pedagogicznych jednoznacznie dowodzi, że pozostaje on nadal poza dydaktyczną refleksją nad nauczaniem i wiedzą szkolną (Klus-Stańska 2010: 147). Niezbędna staje się zatem refleksja nad badaniami dyskursu edukacyjnego. Dyskurs pojmujemy jako „sposób artykułowania istniejących intersubiektywnie przekonań, wyobrażen, ocen, norm, wartości wytworzonych w praktyce społecznej, a szerzej - jako zbiór praktyk komunikowania przeświadczeń, zakorzenionych w osobistym doświadczeniu i kontekście kulturowym, związanych z rozumieniem jakiegoś obszaru rzeczywistości" (Wiśniewska-Kin 2013: 94). Dla podjętych analiz interesujący jest dyskurs edukacyjny, realizujący się w praktyce dydaktycznej jako konsekwencja przekonań teoretycznych (metadyskurs) uzasadniających tę praktykę. 
Cel tego artykułu jest wyraźnie teoretyczny. Jest nim uporządkowanie, naszym zdaniem nieostrych, prób systematyzacji badań dyskursu edukacyjnego. Efektem naszej analizy będzie kategoryzacja zróżnicowanych podejść badawczych. Zadanie niniejszego tekstu jest raczej skromne i dotyczy spraw elementarnych. Z całą pewnością nie jest to szczegółowy wykład poświęcony badaniom dyskursu edukacyjnego. Nie jest to także wykład wyczerpujący (temu służą raczej publikacje zwarte), ale raczej zachęta do podjęcia własnych badań na podstawie zawartych w nim informacji. Dydaktyczne założenie stojące u podstaw naszej wypowiedzi doprowadziło nas do przekonania, że trzeba położyć nacisk bardziej na szkoły niż jednostkowe ujęcia dyskursu edukacyjnego. Nie jest to wreszcie wypowiedź nosząca znamiona szczególnej oryginalności, choć pojawiają się w niej kategorie analityczne i przemyślenia formułowane po raz pierwszy, nieobecne we wcześniejszych próbach usystematyzowania badań nad dyskursem edukacyjnym. Przeprowadzenie takich analiz dyskursu edukacyjnego pozwala, w naszym przekonaniu, nie tylko rozpoznać i wyartykułować odmienności w jego interpretacji, ujawniające się w sposobach jego eksploracji, ale też wskazać nowe możliwości analizy rzeczywistości edukacyjnej. Przyjrzyjmy się bliżej tym wątkom.

\section{Kategorie wyznaczające optykę refleksji}

Różnorodność podejść teoretyczno-metodologicznych, z których perspektywy podejmowane są badania dyskursu, powoduje, że ,badania nad dyskursem mają charakter interdyscyplinarny, a ich uporządkowanie wokół określonych programów czy ujęć bywa trudne, ze względu na to, że w jego definiowaniu i analizie autorzy wskazują na istnienie zróżnicowanych nurtów czy teorii” (Klus-Stańska 2010: 144-145). Złożoność podjętego zagadnienia dostrzegają, próbują rozpoznać i ocenić inicjatorzy projektu „Jak analizować dyskurs? Perspektywy dydaktyczne". Skupieni wokół niego naukowcy przekonują, że „,zakotwiczenie każdego badacza dyskursu w innej tradycji teoretycznej i metodologicznej (nawet poruszając się w jednej tylko - np. polskiej - przestrzeni naukowej) jest na tyle silne, że zbliżanie poglądów staje się problematyczne. [...] Każdy z nich funkcjonuje w różnych stylach myślowych, ponieważ pracuje w różnych kolektywach myślowych. Style myślowe wyrażają się w tym, że każda dyscyplina w różnych przestrzeniach naukowych formułować może inne pytanie badawcze, posługując się przy tym rozmaitymi instrumentami analitycznymi, przez co mamy tak ogromną różnorodność w pojmowaniu pojęcia dyskursu" (Czachur, Kulczyńska, Kumiega 2016: 8).

Nasza propozycja systematyzacji podejść badawczych do dyskursu edukacyjnego zdecydowanie przekracza granice wyznaczane przez dyscypliny naukowe. Ponieważ jednym ze wspólnych mianowników naszych biografii naukowych jest dbałość o pragmatyczną funkcję badań, efektem naszego przeglądu badań dyskursu edukacyjnego jest ich systematyzacja dokonana na podstawie rekonstrukcji przesłanek do zmiany praktyki edukacyjnej obecnych explicite i implicite w sprawozdawczych narracjach autorów opracowań 
badawczych ${ }^{1}$. W wyniku tych działań analitycznych skrystalizowały nam się trzy perspektywy badawcze: optymalizacyjna, analityczna i krytyczna.

\section{Dyskurs edukacyjny w perspektywie optymalizacyjnej}

Typowe dla podejścia optymalizacyjnego w badaniach dyskursu edukacyjnego jest postrzeganie procesu dydaktycznego przez pryzmat językowej formy jego wykonania, przy czym język pojmowany jest wyłącznie jako neutralne narzędzie komunikacji. Dla badaczy zasadniczym celem staje się koncentrowanie na aspekcie poprawnościowym dyskursu, tzn. „na odnajdywaniu deficytów w porządku i strukturze codziennych światów, i stąd na legitymizacji działań naprawczych" (Macbeth 2003: 242).

W „narracjach naprawczych” dominują dwa odmienne podejścia: jedne zmierzają do weryfikacji rzeczywistości edukacyjnej zgodnie z przyjętym teoretycznym ujęciem przedmiotu (Labocha 1996: 9-15; Żydek-Bednarczuk, Zeler 1996: 17-30; Shugar 1996: 49-57; Boniecka 1996: 59-75; Kielar-Turska 1996: 87-97), inne zaś dążą do rozpoznawania rzeczywistości edukacyjnej z perspektywy eksperta „nieujawniającego się”, chociażby przez dobór/wskazanie założeń teoretycznych (Rittel 1996: 99-109; Kawka 1996: 111-121; Synowiec 1996: 203-209).

Przedmiotem zainteresowania staje się diagnozowanie pożądanych w przestrzeni szkoły norm w zakresie lingwistycznych aspektów funkcjonalnych i pragmatycznych w celu optymalizowania dyskursu edukacyjnego. W ujęciu funkcjonalnym analizie poddawane są m.in. środki językowe, głównie pytania i polecenia dydaktyczne (Nocoń 1997) i czytelność tekstów dydaktycznych, tzn. ich dostosowanie na poziomie leksyki i składni do możliwości percepcyjno-językowych odbiorcy - ucznia (Gąsiorek 2007).

Pragmatyczny aspekt badań nad dyskursem edukacyjnym nadaje mu wyraźnie bardziej kontekstualny charakter w ten sposób, że wiąże go z lekcją szkolną, czyli interakcją dydaktyczno-komunikacyjną oraz swoistymi dla niej środkami językowymi, które służą realizacji określonych intencji i funkcji pragmatycznych (Putkiewicz 2002). Szczególnie ciekawe są ujawniające się w toku lekcyjnych interakcji dialogowych (Rutkowiak 1992; Dudzikowa 1996; Śnieżyński 2001) badania pragmatycznej struktury aktów mowy (początków i zakończeń lekcji, poleceń, dyrektyw, rozkazów, form adresatywnych), ich frekwencji w toku lekcji oraz rozkładu pomiędzy nauczycielem a uczniem (Wojtczuk 1996; Kawka 1999; Skowronek 1999; Przybyla 2004).

Wyniki tych badań ujawniają skutki oddziaływania czynników usztywniających i blokujących dyskurs edukacyjny. Najczęściej formułowane zarzuty dotyczą nauczycielskich komunikatów. W większości z nich dominuje bowiem impresywność, wyni-

\footnotetext{
1 Konstruowanie korpusu materiałów rozpoczęłyśmy od analizy jakościowej polskich i anglojęzycznych prac badawczych poświęconych analizie dyskursu edukacyjnego. Korzystałyśmy z już istniejących materiałów, które selekcjonowałyśmy na potrzeby analizy (często kierując się dostępnością materiałów). Zapoznanie się z nimi pozwoliło na zarysowanie cech trzech perspektyw (optymalizacyjnej, analitycznej i krytycznej).
} 
kająca z przewagi sterujących aktów mowy, gra oficjalności z nieoficjalnością, znaczna redundancja tekstu, ujawniająca się w postaci licznych powtórzeń, obecność metatekstów o funkcji korekcyjnej i kontrolnej oraz nieustanne wartościowanie (Nocoń 2013: 125; Wojtczuk 1996).

Optymalizacyjne ujęcie tych badań wyraża się więc w narracjach akcentujących potrzebę równoważenia relacji nauczyciel - uczeń. Sposób konstruowania tych badań pokazuje dezaprobatę dla nauczycielskich prób zaznaczania swojej przewagi, ujawniającej się w asymetrycznym układzie ról komunikacyjnych w sytuacji lekcji szkolnej, o czym zaświadczają zestawienia procentowe: około $70 \%$ wypowiedzi nauczycieli i $30 \%$ wypowiedzi uczniów (Putkiewicz 2002: 32, 42). Z danych tych wynika, że uczeń zazwyczaj występuje w roli zleceniobiorcy pomysłów i projektów nauczyciela, rzadko wpływa na kierunki i strukturę dyskusji. Ten model sytuacji komunikacyjnej jest efektem pewnego typu relacji społecznej, wyznaczonej statusem dorosłego, który występuje w określonej roli wobec dziecka (Kielar-Turska 1996: 96). Interpretacje wyników tych badań przyjmują formę kontestacji.

Aspekt optymalizacyjny badań pozwala nie tylko zdiagnozować czynniki blokujące dyskurs uczniowski, ale też rozpoznać warunki, które zapewniają dziecku aktywne, skuteczne i twórcze uczestnictwo w procesach dyskursywnych. Badacze, odrzuciwszy przekonanie o ograniczonych (rozwojowo) dziecięcych kompetencjach dyskursywnych, decydującą rolę przyznają środowisku edukacyjnemu i oddziaływaniom społeczno-kulturowym, w tym porozumieniu się w środowisku rówieśników i dorosłych (Shugar 1995; Kielar-Turska 1996; Boniecka 1996). Jak wynika z badań, przestrzeń dla dyskursu dziecięcego otwierają: możliwość stymulowania z zewnątrz dziecięcych predyspozycji poznawczych i wypracowanie strategii edukacyjnych o charakterze dialogowym. Analizy dostarczają przekonujących dowodów o konieczności wzmacniania dyskursu dziecięcego w wyniku stwarzania inspirujących sytuacji edukacyjnych (Klus-Stańska 2002; Nowicka 2010; Wiśniewska-Kin 2013; Żytko 2006).

Umożliwia formułowanie tylko takich wniosków, które odnoszą się do faktycznych zdarzeń na lekcjach. Uwaga badaczy koncentruje się na tym, jaki jest uprawomocniony w przestrzeni szkoły wewnątrzosobowy i zewnątrzosobowy kontekst komunikacyjny, co jest typowe dla uczniowskich i nauczycielskich reakcji werbalnych i pozawerbalnych oraz dziecięcych i nauczycielskich sposobów osiągania celów środkami dyskursywnymi w sytuacji inicjowania interakcji z rówieśnikiem lub w sytuacji przekazywania wiedzy, a także jakie są podręcznikowe sposoby modelowania linii aktywności i dynamiki uczniowskich interakcji. W tym sensie optyka optymalizacyjna ujawnia normatywny charakter badań dyskursu edukacyjnego.

Dyskursywny akt komunikacyjny nie jest postrzegany jako obciążony ideologicznie. Ujmowany jako przestrzeń biograficznie i społecznie zdekontekstualizowana, powołany jest raczej do diagnozowania procesu nauczania-uczenia się i wychowania, który można poddawać ocenie zewnętrznych ekspertów (w zakresie chociażby efektywności nauczania czy rozwoju ucznia). Badacze wyposażeni w obiektywne narzędzia oceny - modelowe 
ujęcia przebiegu lekcji zakotwiczone w różnych koncepcjach teoretycznych, usankcjonowanych doświadczeniem „,dobrych praktyk” - przyjmują je za normatywny punkt odniesienia, co ujawnia się w samej konceptualizacji badania i/lub w interpretacjach i języku wniosków z badania. Dyskurs w tej optyce otwarte pozostawia pytania: „Kim jest dziecko? Jakie ma możliwości? Na ile można mu zaufać? Jaką wartość ma jego rozumienie świata? Czemu służy przeżywanie dzieciństwa? W jaki sposób rozwija się człowiek? Jakie skutki tożsamościowe ma władza nad myśleniem?" (Klus-Stańska 2010: 312). Te i wiele innych zagadnień problematyzują badania dyskursu edukacyjnego, które wpisują się w dwie inne z zaproponowanych przez nas perspektyw: analityczną i krytyczną.

\section{Dyskurs edukacyjny z perspektywy analitycznej}

O odrębności perspektywy analitycznej w badaniach dyskursu edukacyjnego może świadczyć wyodrębnienie w anglosaskim „dyskursie nad dyskursem edukacyjnym” kategorii „analitycznej kultury w badaniach lekcji” (Macbeth 2003: 239). Tożsamość badań reprezentujących kulturę analityczną trafnie wyraził jeden z jej reprezentantów, Macbeth. Odwołując się wprawdzie tylko do jednego z jej nurtów, etnometodologii, dowodzi, że w badaniach lekcji „odkrywa ona gęste pola dyskursywnego działania” (Macbeth 2003: 242). Parafrazując Macbetha, kultura analityczna badań wyraża się w ich sproblematyzowaniu tego, jakie coś jest i jak jest tworzone w kontekście, zamiast tego, co nie działa, jak można to zmienić przez zastosowanie wiedzy wynikającej z badań.

Badania dyskursu edukacyjnego prowadzone w języku i logice tej kultury wyrażają zwątpienie w możliwość tworzenia zdekontekstualizowanych opisów rzeczywistości. Konsekwentnie w sposobie konceptualizacji tych badań odzwierciedla się założenie, że wiedza o świecie jest rozwijana pomiędzy ludźmi w ich codziennych interakcjach, co ukierunkowuje uwagę badacza na procesy społeczne jej tworzenia (Parton, O’Byrne 2000).

Przedmiotem analizy badacze czynią językową warstwę dyskursu edukacyjnego. Jej celem nie jest jednak próba odniesienia stanu realnego do modelowego (niezależnie od tego, czy model odwzorowuje pożądany przebieg procesów przekazywania wiedzy czy proporcje między stosowanymi przez nauczyciela metodami pracy, czy też relacje komunikacyjne między nauczycielem a uczniami etc.). Metodologia tych badań opiera się głównie na nieobciążonej zalożeniami obserwacji. Materiałem badawczym, także punktem odniesienia $\mathrm{w}$ analizie, jak i interpretacji, jest to, co uczestnicy dyskursu faktycznie mówią i robią.

Znamienitym przykładem badań tego nurtu w jego etnometodologicznym wydaniu są klasyczne już prace H. Mehana (Mehan 1974, 1979a, 1979b), w których autor skupił się na dynamice pojedynczych interakcji oraz ich sekwencyjnym porządku, by zrozumieć, jak działające podmioty negocjują w interakcjach sensy i znaczenia oraz tworzą swój wspólny świat. W początkowych badaniach Mehan, opisując zrytualizowane wzory komunikacji na lekcji, ukazał życie szkoły publicznej z innej strony i ujawnił obszary znacząco, choć 
nie formalnie kontekstualizujące sukces szkolny. Uchwycił założenia milcząco przyjmowane przez uczestników lekcji, bez których proces lekcyjny nie mógłby się dziać.

Mehan w swojej pracy „Learning lessons” (Mehan 1979a) zredefiniował znaczenia podstawowych kategorii analitycznych $w$ badaniach edukacyjnych. Kompetencja przestała być wartością skalowaną, legitymizującą koncentrowanie się badaczy na brakach i logicznie wyprowadzonych z analizy przesłankach naprawczych (Macbeth 2003: 243). Stała się „własnością interakcyjną oznaczającą konkretną obserwowalną «pracę» ludzi, układającą się w uporządkowane całości” (Mehan 1979a: 130). Kompetentnym uczestnikiem procesu lekcyjnego stał się ten, który podtrzymuje rytuał. Odkrytymi przez Mehana rytualnymi całościami są „pytania ze znaną odpowiedzią” (Question with the Known Answer) czy sekwencja ,inicjacja-odpowiedź-ewaluacja” (Initiation-Response-Evaluation) (Mehan 1979b). Zobrazował też wzory układania się tych sekwencji w dyskurs ,instruktażowy” (instructional). Mehan opisał, jak ta interakcyjna organizacja konstytuuje się społecznie przy wspólnym udziale nauczycieli i uczniów i tworzy własną konstrukcję dyskursywną.

Wyniki analiz Mehana stały się modelowym przykładem etnometodologicznego wglądu w dyskurs edukacyjny i dały początek pewnej tradycji oglądu procesów lekcyjnych (Cazden, John, Hymes 1972; Gumperz, Hymes 1972; Mishler 1979; Payne, Hustler 1980, 1982; Schultz 1978; Schulz, Florio 1979; Sinclair, Coulthard 1975 etc.). Analiza tych prac wykazuje, że interakcyjny opis zdarzeń lekcyjnych jest wzbogacony o narracje optymalizacyjne. Przykładem takiej niejednoznacznej w opisie narracji o dyskursie edukacyjnym są badania Cazden (2001), w których rozróżnia ona lekcje tradycyjne (traditional lessons), z dominującą sekwencją organizacyjną ,inicjacja-odpowiedź-ewaluacja” i lekcje niestandardowe, czyli te, które odbiegają od tej sekwencji z powodu zmienionego celu edukacyjnego (Cazden 2001: 31). Interpretacje wyników jej badań wybiegają poza działania lekcyjne. Ujmują związki między efektywnością nauczania a strategią organizacji lekcji, co wskazuje na odnoszenie się w interpretacji do jakiejś „,rzeczywistości zewnętrznej" wobec tej konstruowanej w przebiegu procesu lekcyjnego.

Oprócz opisów elementarnych sekwencji organizacji lekcji badania reprezentujące kulturę analityczną mogą dostarczać ujęć rekonstruujących intersubiektywne znaczenia i sensy, którymi wyraża się poczucie wspólnego bądź odrębnego świata nauczycieli i uczniów. Za ich empiryczną egzemplifikację można uznać interakcyjno-symboliczną analizę procesu wykluczania społecznego dzieci (mieszkańców i młodzieży jednego ze starołódzkich sąsiedztw), obejmującą m.in. przestrzeń interakcji szkolnych, w tym lekcyjnych (Gulczyńska 2013). W rezultacie tych badań zobrazowano, jak dyskurs lekcyjny podporządkowuje się regułom procesu tworzenia i podtrzymywania tożsamości społecznej uczniów i nauczycieli, z których każdy odnosi się w swych wzajemnych interakcjach do odmiennych perspektyw symbolicznych. Opisy interakcji pomiędzy uczniami a nauczycielami ujawniają, jak wychowawcza i dydaktyczna warstwy dyskursu stają się jedynie tłem dla tego, co jest faktycznie znaczące dla interlokutorów w przebiegu procesu lekcyjnego (Gulczyńska 2013). 
Niezależnie od tego, że w badaniach dyskursu edukacyjnego reprezentujących kulturę analityczną unika się ujmowania a priori badanej rzeczywistości w ramy modeli teoretycznych czy jej prekonceptualizacji na podstawie innych przesłanek ułatwiających jej ocenę i definiowanie przesłanek do jej doskonalenia, teoretyczne rezultaty tych badań mogą istotnie orientować procesy zmiany praktyk edukacyjnych. W wyniku prowadzonych analiz krystalizują się bowiem teoretyzacje potocznej organizacji lekcji i/czy struktury sensów i znaczeń tworzonych we wspólnym doświadczeniu uczestników dyskursów szkolnych. W wyniku tych badań powstają teorie na temat tego, co faktycznie dzieje się na lekcji, tworzone jednak bez intencji waloryzowania na podstawie modeli, norm lub oczekiwań zewnętrznych wobec rekonstruowanej rzeczywistości edukacyjnej. Te oddolne rekonstrukcje ,ukrytych dyskursów” ujawniają to, co tworzone jest przez aktorów społecznych niejako ,pod spodem” formalnej struktury lekcyjnej, a co znacząco kontekstualizuje jej efekty. Ponieważ przedmiotem odkrycia są nieuświadomione przez uczestników lekcji reguły ich własnych działań, wyniki tych badań analitycznych zawieszają „oczywistość”, pobudzają oryginalną refleksję, nieograniczoną koncepcjami wyjściowymi i/lub własnym doświadczeniem nauczyciela.

Eksponowanie perspektywy podmiotu w oglądzie dyskursu sprzyja redefinicji pojęcia diagnozy edukacyjnej i wiedzy eksperckiej. Inspiruje do odwrócenia logiki typowego procesu wprowadzania zmian w praktykach edukacyjnych. Zmiany inicjowane odniesieniami do modelu (z reguły legitymizowanego badaniami) zostają zastąpione działaniami, którym początek i kierunek daje to, co realne w lokalnych rzeczywistościach edukacyjnych. W efekcie tych badań mogą powstawać intersubiektywne konstrukcje modelowe, bliższe codziennej praktyce edukacyjnej.

W obliczu przyjętych założeń rodzą się wątpliwości, czy rekonstruktywistyczne ujęcie praktyk edukacyjnych nosi w sobie potencjał ich odważnej zmiany, czy raczej w zakamuflowany sposób służy ich utrwaleniu. Uznanie podmiotu jako źródła i współtwórcy wartościowej wiedzy o dyskursie edukacyjnym nosi w sobie potencjał pomyślnej zmiany, gdyż sprzyja demokratyzacji procesów edukacyjnych, z drugiej jednak strony wyabstrahowanie prowadzonych analiz dyskursów lekcyjnych z szerszych struktur - społeczno-ekonomicznych, kulturowych, politycznych etc. - wyznaczających ramy obserwowanych interakcji pozostawia badaczy nieczułymi na te struktury. Uzasadnienie tej wątpliwości odnajdujemy w stanowisku M. Czyżewskiego, który w swej socjologicznej refleksji nad znaczeniem badań interpretatywnych dla zmiany społecznej zauważył, że „dzisiaj, podobnie jak u swych chicagowskich źródeł, socjologia interpretatywna bezkrytycznie wpisuje się w rządomyślną normalizację życia społecznego, która nie domaga się spełniania z góry założonych norm, lecz nastawia się na optymalizację rzeczywistości wokół empirycznie stwierdzalnych trendów" (Czyżewski 2013: 3). Podobne argumenty odnajdujemy w badaniach dyskursów edukacyjnych prowadzonych z perspektywy krytycznej. 


\section{Dyskurs edukacyjny w perspektywie krytycznej}

Istota krytycznych badań dyskursu edukacyjnego sprowadza się do rozpoznania „ukrytych treści” w interakcjach lekcyjnych. Dyskurs jest rozpatrywany jako przestrzeń obciążona ideologicznie. W jego treściach odzwierciedlają się zewnętrzne dyskursy, służące $\mathrm{w}$ istocie podtrzymaniu interesów wybranych, uprzywilejowanych grup. W tym sensie badacze upatrują w nim instrument wladzy.

Krytyczna analiza dyskursu obejmuje szereg badań, których wspólnym mianownikiem jest usytuowanie władzy, ideologii i asymetrycznych relacji władzy w centrum prowadzonych analiz. Jej ramami, zakorzenionymi we Frankfurckiej Szkole Krytycznej (Adorno 1973; Adorno, Horkeimer 1992; Marcuse 1966) są zróżnicowane podejścia teoretyczne: „krytyczna teoria rasy [critical race theory], poststrukturalizm, postmodernizm, studia neokolonialne, teoria queer etc., koncentrujące się na władzy i sposobach, w jakie ekonomia, klasa, płeć, religia, edukacja i orientacja seksualna konstruują reprodukuje czy zmieniają systemy społeczne” (Rogers i in. 2005: 368). Analizy inspirowane tymi podejściami „odrzucają naturalizm (założenie, że praktyki społeczne, pojęcia i programy oddają rzeczywistość), racjonalność (założenie, że prawda jest rezultatem nauki i logiki), neutralność (założenie, że prawda nie odzwierciedla żadnych interesów) i indywidualizm" (Rogers 2011: 4).

Krytyczni badacze dyskursu edukacyjnego starają się zrozumieć nie tylko związki między własnościami tekstu edukacyjnego a wybranymi dyskursami, ale i związki między tymi dyskursami a korespondującymi z nimi praktykami społeczno-kulturowymi. Dyskurs edukacyjny w badaniach krytycznych, inaczej niż w badaniach analitycznych, nie jest definiowany jako konstrukcja społeczna współtworzona oddolnie, w naturalnych warunkach instytucji edukacyjnej, ale jest strukturą konwencji uporządkowanych „we” władzy i ,poprzez” władzę, której odczucie nie jest dostępne samym uczestnikom procesu lekcyjnego. Tak jak w podejściu analitycznym doceniano lokalny ład światów etnograficznych i przyznano uczestnikom rolę ekspertów od niego, tak w krytycznych analizach dyskursu badacza interesować będzie to, czego interlokutorzy nie wiedzą o organizacji, którą jednak aktywnie współtworzą. Krytyczny wgląd w przebieg lekcji osadza badacza w roli eksperta, który interpretuje badaną rzeczywistość przez pryzmat w pewien sposób prekonceptualizowanych ram teoretycznych.

Wachlarz tych ram przekłada się na zróżnicowanie pytań badawczych. W krytycznych analizach tego, co się dzieje w procesach uczenia i nauczania, odkrywa się wielość odcieni wzajemnych powiązań pomiędzy programem nauczania, tworzeniem dyskursu edukacyjnego, władzą i wiedzą.

Wśród badań krytycznych dyskursu edukacyjnego znajdujemy te, które sposoby wzmacniania instytucjonalnej i ogólnospołecznej kontroli odkrywają w nauczycielskich praktykach uprzywilejowywania wybranych typów wiedzy czy doświadczeń kosztem wykluczania innych.

Kontrolna funkcja szkoły, wyrażana odpowiednim doborem treści w dyskursie lekcyjnym, została wymownie ujęta przez Douglasa Browna i Jennifer Kelly. W swoich bada- 
niach interesowali się wzajemnymi związkami między dynamiką dyskursu edukacyjnego a światami przeżywanymi uczniów reprezentujących mniejszości kulturowe (Brown, Kelly 2001). Na podstawie materiału z wywiadów fokusowych, przeprowadzonych na lekcjach WOS w jednym z kanadyjskich liceów w dwóch grupach uczniów reprezentujących mniejszości afrykańskie, wyprowadzono tezę o dyskryminacji ich historii i doświadczeń życiowych oraz o związku tej szkolnej praktyki z ukrytą funkcją szkoły: pogłębianiem marginalizacji mniejszości etnicznych przez ignorowanie alternatywnych światopoglądów.

Inny przykład wpływu nauczyciela na proporcje poszczególnych typów wiedzy w procesie jej dyskursywnego tworzenia został uchwycony w badaniach Lilie Chouliaraki (1998). Odwołując się w analizie interakcji nauczyciel - uczeń do Bernsteinowskiego pedagogicznego dyskursu², odkryła ona w przebiegu lekcji praktyki interakcyjne, które „rekontekstualizują” dyskursy i wiedzę, by służyć kontroli instytucjonalnej. W wyniku badania odkryte zostały własności tekstualne interakcji nauczyciel - uczeń (np. rozległe używanie modalności językowej), które w subtelny sposób akcentowały silniej wiedzę „proceduralną” czy ,rytualną” niż naukową (principled). Dokonywane przez nauczyciela wartościowanie wiedzy wydawało się wzmacniać przygotowanie uczniów zorientowanych na wykonywanie zadań, a nie na rozwijanie autonomii i kreatywności w procesie uczenia się.

Inspiracje Bernsteinowską koncepcją dyskursu pedagogicznego obecne są również w badaniu Kristiny Love, zmierzającym do ujawnienia strategii uprawomocniania ideologicznych związków z edukacją szkolną w procesach interpretacyjnych konstruowanych w przebiegu lekcji. Analizy obejmowały nauczycielskie praktyki dyskursywne na lekcjach angielskiego w klasach australijskiego gimnazjum, zmierzające do urealnienia tych typów uczniowskiego wnioskowania, które były zgodne z kulturowo akceptowanymi wartościami (Love 2000). Jeszcze inne analizy koncentrują się na społecznie aprobowanych wzorach tworzenia dyskursu edukacyjnego. W sposobach ich problematyzowania badacze wyrażają rozumienie dyskursu edukacyjnego jako przestrzeni manifestowania i utrwalania reprodukcji tradycyjnego systemu wartości czy podziału ról w społeczeństwie. Przykładem takich badań jest analiza dyskusji między wykładowcami a studentami jednego z amerykańskich uniwersytetów (Bergvall, Remlinger 1996). Badaczki starały się rozpoznać w przebiegu zajęć akademickich znaczenie dialogu instruktażowego (instructional talk) i odbiegających od niego rozmów w reprodukcji bądź podważaniu ładu społecznego wyznaczanego płcią. Swoim badaniem udokumentowały różne sposoby, w jakie kobiety i mężczyźni kontestowali to, że reprezentanci przeciwnej płci kontrolowali dyskusję. Tak jak mężczyźni starali się zaburzyć przebieg dyskusji zachowaniami nastawionymi na niekonstruktywne zaburzanie jej toku (np. przez kpiarskie wtrącenia), tak kobiety próbowały zmienić jej przebieg przez zastosowanie raczej technik otwierających dyskusję na rozwój, na różne możliwości.

2 B. Bernstein definiował to pojęcie jako „zbiór reguł wyspecjalizowanych form komunikowania, w wyniku którego dokonuje się zróżnicowana transmisja kultury i jej zróżnicowane przyswajanie" (Bernstein 1990: 171). 
W powyższych przykładach projektów badawczych już sam fakt głębokiego i zaangażowanego osadzenia badacza w prawdziwym życiu i problemach społecznych czyni z niego szczególnego promotora zmiany. Jakkolwiek ich analiza pozwala zauważyć pewną niekonsekwencję. Badacze powołują się w celach badań na demaskację powiązań władzy i wiedzy, ale jednocześnie wciąż sami zdają się je pielęgnować, co ujawnia się w ich wyborach metodologicznych. Zachowywany przez nich podział na badacza i badanych podtrzymuje krytykowany typ relacji władzy, jakkolwiek w innym kontekście społecznym.

Zmiana tego stanu rzeczy wymagałaby od krytycznych badaczy dyskursu edukacyjnego otwarcia na metodologie badań, które redefiniują relację władzy między nimi a badanymi na możliwie wielu etapach badania, od jego konceptualizacji poprzez zebranie, analizę materiału empirycznego, interpretację i tworzenie ostatecznego rezultatu teoretycznego aż po popularyzację wyników. Inspiracją mogą być badania partycypacyjne. Uczestnictwo w tych badaniach bywa różnie rozumiane ${ }^{3}$. Cechami istotnościowymi badań, które są nam bliskie, jest dbałość o równy podział władzy w przebiegu badania. Wyraża się ona wspóltworzeniem wiedzy (collaborative creation of knowledge) (Jagosh i in. 2011) przez wszystkich uczestników badania oraz znoszeniem podzialów na badaczy i badanych. Badania takie umożliwiają „,zmianę roli badań z poszerzania wiedzy i władzy profesjonalistów na uwolnienie i emancypację uczestników badania, a to możliwe jest jedynie wtedy, gdy oni sami będą mieli udział zarówno w opracowywaniu procedur badawczych, jak i realizacji poszczególnych jego etapów" (Granosik, Gulczyńska 2014: 19).

Tak rozumiane badania partycypacyjne wydają się stanowić ciekawą przestrzeń dla zmian w edukacji dokonywanych współbieżnie z upełnomocnieniem uczniów. Mogłyby być one konstruowane wspólnie z przedstawicielami środowisk akademickich, którzy porzuciliby realizację nowego „reżimu władzy”, a weszli w rolę faktycznych rzeczników spraw uczniów.

Zrekonstruowanie trzech perspektyw (optymalizacyjnej, analitycznej i krytycznej) w badaniach dyskursu edukacyjnego dostarcza ciekawych inspiracji dla refleksji o edukacji. Zwraca uwagę na różne możliwości odczytania ich pragmatycznej funkcji. W przypadku badań optymalizacyjnych akcentowane są przede wszystkim skutki oddziaływania czynników usztywniających i blokujących dyskurs edukacyjny, a także potrzeba rozpoznania warunków, które zapewniają dziecku aktywne, skuteczne i twórcze uczestnictwo w procesach dyskursywnych. Nieobarczone prekonceptualizacjami teoretycznymi rekonstrukcje sekwencyjnego porządku lekcji uzyskane w badaniach analitycznych mogą stać się podstawą oddolnie wprowadzanych zmian, których kierunek będzie bardziej odzwierciedlał perspektywę przeżywającego podmiotu niż zewnętrzne wobec badanej rzeczywistości modele, utrwalone naukową weryfikacją, ideologią czy tradycją. Natomiast empiryczne poszukiwania krytycznych badaczy dyskursu odkrywają zakamuflowane strategie

3 W wachlarzu terminów wyrażających różne formy badań partycypacyjnych odnajdujemy różne metodologie: action-research (Elliott 1991), action inquiry (Torbert 1991), participatory research (Beresford 2014), partcipatory action research (Fals-Borda, Rahman 1991), emancipatory action research (Kemmis 2001), critical participatory research (Torre 2009). 
edukacyjne, służące społecznej reprodukcji. Ujawniają rozbieżność między deklarowanymi a rzeczywistymi celami szkolnej edukacji i inspirują do działań sprzyjających emancypacji oraz wychowywaniu świadomych podmiotów.

Zaprezentowana przez nas próba systematyzacji badań nad dyskursem edukacyjnym postuluje potrzebę silnego umocowania w teorii badań dyskursu edukacyjnego. Wymaga ona dalszej pracy analitycznej, której celem byłoby silniejsze nasycenie kategorii badań analitycznych i krytycznych. Dyskusyjną stroną naszej analizy jest bowiem sposób doboru tekstów, na podstawie których wyodrębnione zostały cechy dystynktywne tych dwóch kategorii. Naszym celem jednak nie było stworzenie kategorii rozstrzygających. Dostrzegamy potrzebę kontynuowania analiz doprecyzowujących kryteria rozłączności zaproponowanych kategorii. Szczególnie zależy nam na uwrażliwieniu odbiorcy na związek wybranych podejść badawczych ze sposobami uzasadnienia zmian i określenia kierunku, w którym miałyby zdążać. „Wrażliwy” z natury organizm, za jaki można uznać każdy model edukacji, nie powinien być poddawany chaotycznym, przypadkowym czy powierzchownym działaniom naprawczym, choćby w najlepszej wierze. Wydaje się, że szkoła jest „skazana” na permanentne zmiany, ale ze względu na swoje funkcje musi być zanurzona w całym spektrum zmian, jakie się dokonują w dyscyplinach naukowych, zwłaszcza stanowiących najbliższy kontekst dyscypliny macierzystej, pedagogiki, i - w jej obrębie - dydaktyki. Zawarte w niniejszym tekście rozważania poniekąd są próbą zarysowania tej zmiany, ze szczególnym uwzględnieniem przekształceń wynikających z pojmowania edukacji w perspektywie badań dyskursu edukacyjnego i ściśle wiążą się ze wspólnym przedmiotem naszych zainteresowań, którym jest społeczna odpowiedzialność badaczy za kształt rzeczywistości edukacyjnej.

\section{Literatura}

Adorno T. (1986), Dialektyka negatywna. Przeł. K. Krzemieniowa, Warszawa, PWN.

Adorno T., Horkheimere M. (1994), Dialektyka oświecenia. Fragmenty filozoficzne. Przeł. M. Łukasiewicz, Warszawa, Wydawnictwo IFiS PAN.

Bergvall V., Remlinger, K. (1996), Reproduction, resistance, and gender in educational discourse: The role of critical discourse analysis. „Discourse \& Society”, 7(4).

Beresford P. (2014), Upetnomocniająca wiedza dla upetnomocniającej pracy socjalnej. W: A. Gulczyńska, M. Granosik (red.), Empowerment w pracy socjalnej: praktyka i badania partycypacyjne. Warszawa, Centrum Rozwoju Zasobów Ludzkich.

Bernstein B. (1990), Odtwarzanie kultury. Przeł. Z. Bokszański, A. Piotrowski. Wrocław, PIW.

Boniecka B. (1996), O modelowaniu sytuacji na przykładzie wypowiedzi dzieci w wieku przedszkolnym. W: T. Rittel (red.), Dyskurs edukacyjny. Kraków, Wydawnictwo WSP.

Brown, D., Kelly, J. (2001), Curriculum and the classroom: Private and public spaces, „British Journal of Sociology of Education", 22(4).

Carr, W., Kemmis, S. (1986), Becoming critical: Education, knowledge, and action research. London, Falmer. 
Chouliaraki L. (1998), Regulation in 'Progressivist'Pedagogic Discourse: Individualized TeacherPupil Talk. „Discourse \& Society”, 9 (1).

Cazden C B., John V., Hymes D. (1972), Functions of languages in the classroom. New York, Teachers College Press.

Cazden, C.B. (2001), Classroom Discourse: The Language of Teaching and Learning. Portsmouth, NH: Heinemann.

Czachur W., Kulczyńska A., Kumiega Ł.(2016). Jak analizować dyskurs? Perspektywy Dydaktyczne. Kraków, Universitas.

Czyżewski M. (2013), Socjologia interpretatywna i metoda biograficzna: przemiana funkcji, antyesencjalistyczne watpliwości oraz sprawa krytyki. „Przegląd Socjologii Jakościowej”, t. 9, nr 4, www.przegladsocjologiijakosciowej.org [04.01.2017].

Dudzikowa M. (red.) (1996), Nauczyciel - uczeń. Między przemoca a dialogiem: obszary napięć i typy interakcji. Kraków, Oficyna Wydawnicza Impuls.

Elliott J. (1991), Action research for educational change. Milton Keynes England, Philadelphia, Open University Press.

Fals-Borda O., Rahman M.A. (1991), Action and Knowledge: breaking the monopoly with participatory action research, New York, Intermediate Technology Pubs/Apex Press.

Gąsiorek K. (2007), Wskaźnik czytelności podręczników dla klas I-III szkoły podstawowej w ujęciu diachronicznym. W: H. Synowiec (red.), Podręczniki do ksztatcenia polonistycznego $w$ zreformowanej szkole - koncepcje, funkcje, język. Kraków, Wydawnictwo Edukacyjne.

Granosik M., Gulczyńska A. (2014) Empowerment i badania w pracy socjalnej. W: A. Gulczyńska, M. Granosik (red.), Empowerment w pracy socjalnej: praktyka i badania partycypacyjne. Warszawa, Centrum Rozwoju Zasobów Ludzkich.

Gulczyńska A. (2013) Chłopaki z dzielnicy. Studium społeczno-pedagogiczne z perspektywy interakcyjnej. Łódź, Wydawnictwo UŁ.

Gumperz J., Hymes D. (1972), Directions in sociolinguistics: The ethnography of communication. New York, Holt, Reinehart\&Winston.

Jagosh J., Pluye P., Macaulay A.C., Salsberg J., Henderson J. (2011), Assessing the outcomes of participatory research: Protocol for identifying, selecting, appraising and synthesizing the literature for realist review. „Implementation Science”, 6(1).

Kawka M. (1996), Powiedz to catym zdaniem - czyli o metatekstowych wyktadnikach dyskursu. W: T. Rittel (red.), Dyskurs edukacyjny. Kraków, Wydawnictwo WSP.

Kawka M. (1999), Dyskurs szkolny. Zagadnienia języka. Kraków, Wydawnictwo WSP.

Kemmis S. (2010), Teoria krytyczna i uczestniczace badania w działaniu, W: H. Červinková, B.D. Gołębniak (red.), Badania $w$ działaniu. Pedagogika i antropologia zaangażowane. Wrocław, Wydawnictwo Naukowe DSW.

Kielar-Turska M. (1996), Uczeń w interakcji z rówieśnikiem lub dorosłym. W: T. Rittel (red.), Dyskurs edukacyjny. Kraków, Wydawnictwo WSP.

Klus-Stańska D. (2010), Dydaktyka wobec chaosu pojęć i zdarzeń. Warszawa, Wydawnictwo Akademickie Żak.

Klus-Stańska D. (2010), Konstruowanie wiedzy w szkole. Olsztyn, Wydawnictwo UWM.

Labocha J. (1996), Dyskurs jako proces przekazywania wiedzy. W: T. Rittel (red.), Dyskurs edukacyjny. Kraków, Wydawnictwo WSP.

Love K. (2000), The Regulation of Argumentative Reasoning in Pedagogic Discourse. „Discourse Studies", 2(4). 
Macbeth D. (2003), Hugh Mehan's "Learning lessons" Reconsidered: On the Differences Between the Naturalistic and Critical Analysis of Classroom Discourse. „American Educational Research Journal", 40(1).

Marcuse H. (1966), Rozum i rewolucja. Łódź, Książka i Wiedza.

Mehan H. (1974), Accomplishing classroom lessons. W: A. Cicourel (red.), Language, use and school performance. New York, Academic Press.

Mehan H. (1979a), Learning lessons. Cambridge, MA: Harvard University Press.

Mehan H. (1979b), "What time is it Denis?" Asking known information questions in classroom Discourse. „Theory into Practice”, 18(4).

Mishler E (1979), Meaning in context: Is there any other kind? „Harvard Educational Review”, 49(1).

Nocoń J. (1997), Polecenia i pytania w podręcznikach do nauki o języku. Opole, Wydawnictwo TiT.

Nocoń J. (2013), Styl dydaktyczny - styl dyskursu dydaktycznego. W: E. Malinowska i in. (red.), Style współczesnej polszczyzny. Przewodnik po stylistyce polskiej. Kraków, Universitas.

Nowicka M. (2010), Socjalizacja na lekcjach w klasach początkowych. Praktyki - przestrzenie konceptualizacje. Torun, Wydawnictwo Adam Marszałek.

Parton, N., O'Byrne, P. (2000), What do We Mean by Constructive Social Work? "Critical Social Work", 1(2). http://www.gptsw.net/papers/constsw.pdf [19.12.2016].

Payne G.C.F., Hustler D.E (1980), Teaching the class: The practical management of a cohort. „British Journal of Sociology of Education", 1(1).

Payne G.C.F., Hustler D.E (1982) Doing teaching. London, Batesford Academic Press.

Przybyla O. (2004), Akty mowy w języku nauczycieli. Katowice, Wydawnictwo UŚ.

Putkiewicz E. (2002), Proces komunikowania się na lekcji. Warszawa, Wydawnictwo APS.

Rittel S.J. (1996), Modelowanie dyskursu edukacyjnego. W: T. Rittel (red.), Dyskurs edukacyjny. Kraków, Wydawnictwo Naukowe WSP.

Rittel T. (red.). (1996), Dyskurs edukacyjny. Kraków, Wydawnictwo Naukowe WSP.

Rogers, R. (2011), An introduction to critical discourse analysis in education. New York, Routledge.

Rogers R., Malancharuvil-Berkes E., Mosley M, Hui D., O'Garro Joseph G. (2005), Critical Discourse Analysis in Education: A Review of the Literature. „Review of Educational Research Fall”, 75 (3).

Rutkowiak J. (red.) (1992), Pytanie, dialog, wychowanie. Warszawa, PWN.

Shugar G.W. (1995), Dyskurs dziecięcy. Rozwój w ramach struktur spolecznych. Warszawa, Wydawnictwo Energeia.

Shugar G.W. (1996), Dyskurs dziecięcy. Początki i źródta rozwoju. W: T. Rittel (red.), Dyskurs edukacyjny. Kraków, Wydawnictwo Naukowe WSP.

Skowronek B. (1999), O dialogu na lekcjach w szkole średniej. Analiza pragmatyczno-językowa. Kraków, Wydawnictwo Naukowe AP.

Schultz J. (1978), When is a context? Some issues and methods in the analysis of social competence. „Quaterly Newsletter of the Institute for Comparative Human Development”, 1(2).

Schultz J., Florio S. (1979). Stop and freeze: The negotiation of social and physical space in kindergarten/first grade classroom. „Anthropology and Education Quarterly”, 10.

Sinclair J.M., Coulthard M. (1975) Towards an analysis of discourse. London, Oxford University Press.

Śnieżyński M. (2001), Dialog edukacyjny. Kraków, Wydaw. Naukowe PAT. 
Torbert W.R. (1991), Teaching Action Inquiry. W: P. Reason (red.), Collaborative Inquiry, Vol. 5. Centre for the Study of Organizational Change and Development, University of Bath.

Wiśniewska-Kin M. (2013), Dominacja a wyzwolenie. Wczesnoszkolny dyskurs podręcznikowy i dziecięcy. Łódź, Wydawnictwo UŁ.

Wojtczuk K. (1996), Zachowania językowe nauczycieli w sytuacji lekcji szkolnej. Siedlce, Wydawnictwo WSRP.

Żydek-Bednarczuk U., Zeler B. (1996), Strategia i komunikacja $w$ dyskursie edukacyjnym. W:

T. Rittel (red.), Dyskurs edukacyjny. Kraków, Wydawnictwo WSP.

Żytko M. (2006), Pisanie - żywy język dziecka. Warszawa, Wydawnictwo UW. 